\title{
German Nationalism and Its Influence on the Evangelical Church of the Augsburg Confession in Poland 1917-1939
}

\author{
Filip Lipiński (iD) https://orcid.org/0000-0001-6353-2280 \\ Theologische Fakultät \\ Universität Leipzig \\ filip.lipinski@luteranie.pl
}

\begin{abstract}
The roots of German nationalism among members of the Evangelical Church of the Augsburg Confession in Poland are bound with the activity of German authorities who tried to separate the German community in the occupied Kingdom of Poland during the First World War. German nationalism of the era was based on religious, social, and political factors, such as the idea of a unified German nation both within and outside of the German Reich. According to this idea, the German state was to be the defender of the German people worldwide. Such ideas woke the separatist tendencies inside the Augsburg Church. The political situation in the Second Polish Republic and spread of the national socialist ideology in the 1930s increased the separatist tendencies in the Church and led to a conflict with its pro-governmental Consistory and the General Superintendent, later Bishop Juliusz Bursche.
\end{abstract}

Keywords: Church, Lutheran, Poland, German nationalism, Nazi movement, Second Polish Republic

Słowa kluczowe: Kościół, luterański, Polska, niemiecki nacjonalizm, ruch nazistowski, II Rzeczpospolita

\section{Introduction}

What dominates the history of the Augsburg Church in the interwar period is a conflict between two visions of the Church held by the main groups active between 1918 and 1939. One group, associated with Bishop Juliusz Bursche and his supporters, preached the idea of a multinational Lutheran Church that would reflect patriotism and loyalty towards the Polish State. The other group was made up of German pastors 
and Church activists who based their theological and political standpoint on the ideas of German nationalism and the Theology of Orders of Creation, where social and religious factors - that is German ancestry, culture and Protestantism, in a situation when the majority of the Church members declared German nationality - served as an argument to establish an exclusive identity of the Church.

The Second Polish Republic consisted of a multicultural and multiconfessional society, where Poles constituted only approximately 70 percent of all citizens. The German minority made up about 3 percent (approx. 770,000) of the population. Most of the 500,739 Germans living in Poland declared Protestant confession. Among all Protestants in Poland, altogether 180,301 members of different Lutheran, Reformed and Evangelical United Churches, declared Polish nationality.

Before the outbreak of the Second World War the Evangelical Church of the Augsburg Confession was the biggest Protestant Church in Poland, with 524,575 Lutherans. ${ }^{1}$ Most of its members were Germans or Poles of German origin - descendants of settlers, mostly from Prussia, Saxony and Swabia, who moved to Central Poland after the Napoleonic wars. Approximately 75 percent $(392,275)$ of all members of the Augsburg Church declared German nationality, and the only region where the Polish Lutheran population predominated was Cieszyn Silesia. ${ }^{2}$ The activity of the Polish government, the policy of approvals and disapprovals of various Church servants ordained and nonordained, combined with Polish nationalism and the policy of unconditional loyalty towards the state, created a situation where the German majority of the Church had only one representative in the highest administrative body - the Consistory. ${ }^{3}$ This political factor provoked the opposition of German pastors and intellectuals against the state itself and the Consistory, which tended to show loyalty towards the state but was considered in particular circles as disloyal towards the Church it represented.

The author's intention is to present the causes and effects of conflicts that took place in the Evangelical Church of the Augsburg Confession in Poland, leading to increasing divisions and mutual national resentment.

\section{5-1918: The roots of the nationalism of the German community in the Church}

One of the grounds of the conflict between German and Polish Lutherans in the Augsburg Church in Poland was the policy of the occupying forces who conquered the territory of the Kingdom of Poland in 1915. The authorities installed by the government of the German Empire probably intended to treat the Congress Poland as a colonial puppet state. Therefore the German minority was to be granted separate laws which would create the possibility of establishing a colonial regime in the event that

${ }^{1}$ P. Ciecieląg, E. Jóźwiak, A. Godfrejow-Tarnogórska (eds.), 500 lat Reformacji w Polsce, Warszawa 2017, p. 65.

2 Ibidem.

${ }^{3}$ E. Kneifel, Geschichte der Evangelisch-Augsburgischen Kirche in Polen, Niedermarschacht über Winsen/Luhe 1962, p. 207. 
the First World War was victorious for the Central Powers. As already mentioned, German schools had been provided with separate jurisdiction. Similar status had been granted to German trade societies and political organisations. Because most of the German colonists, who were the ancestors of settlers who had migrated to then Russian-controlled Poland in the first half of the tenth century, were of the Lutheran faith, the Lutheran Church was also to be subject to the imperialistic policies of the German Reich.

The Evangelical Church of the Augsburg Confession in the Kingdom of Poland gained its legal status in 1849. According to an edict of the Russian Tsar, the Church gained its combined state-consistorial order, where all the administration had to be approved by the state authorities. ${ }^{4}$ During the autonomy of the Kingdom of Poland under the Russian Empire, all administrative decisions had to be discussed with the state authorities based in Warsaw. Later, especially after the January Uprising of 1863, the prerogatives of the royal ministries were given to the Russian confessional authorities in Saint Petersburg. The President of the Consistory, the Vice-President (who also served as the General Superintendent of the Church) and the other members of the Consistory had to be approved by the Russian Tsar, who also held the title of King of Poland. ${ }^{5}$ In practice this administrative jurisdiction was granted to the representative of the Tsar - the Viceroy (Polish: Namiestnik), and later, after the abolition of the autonomy, to the Governor-General of Warsaw (Polish: Generatgubernator warszawski). The General Synod of the Church served as a consulting body, where ordained and non-ordained representatives of particular dioceses could discuss the internal affairs of the Church. During the German occupation of Congress Poland, the prerogatives of the King of Poland were granted by the occupying forces to the newly created Regency Council (Polish: Rada Regencyjna), a temporary Polish state authority. In 1917 the administrative supervision of the state over the Church was given to the Department of the Religious Confessions and Public Enlightenment of the Temporary State Council of the Kingdom of Poland.

The occupying forces, as mentioned above, intended to guarantee the separate status of all German institutions in Poland. The same fate was to meet the Augsburg Church. Already in the first year of the occupation, Lutheran parishes, which suffered from a lack of spiritual care due to the forced exile of ordained ministers to the Russian interior, were seized by pastors sent in by the Reich. ${ }^{6}$ The main task of the new ministers was to strengthen the German national identity among Lutherans living in Poland. One of these pastors was the Lutheran theologian Paul Althaus the Younger. ${ }^{7}$ Pastors who had already served in Congress Poland before the First World War and opposed the way the new authorities treated their Church were in some cases arrested and incarcerated. This elicited a reaction not only from the Polish pastors, such as

${ }^{4}$ Dz. Pr. 1849, t. 42, nr 129, Ustawa dla Kościoła Ewangelicko-Augsburskiego w Królestwie Polskiem.

${ }^{5}$ Dz. Pr. 1849, t. 42, nr 129, §110, §125, §126.

${ }^{6}$ J. Kłaczkow, Kościół Ewangelicko-Augsburski w Polsce w latach 1918-1939, Torun 2018, p. 85.

${ }^{7}$ R. Liebenberg, Der Gott der feldgrauen Männer. Die theozentrische Erfahrungstheologie von Paul Althaus d. J. im Ersten Weltkrieg, Leipzig 2008, pp. 221-439. 
Ryszard Paszko, who worked to strengthen the Polish national identity in his congregation in Koło, ${ }^{8}$ but also German ministers such as Pastor Gustav Friedenberg who refused to accept the will of the new authorities and declared their loyalty towards the Russian Tsar. ${ }^{9}$

The Consistory in Warsaw was also seized by the Germans. In the Tsarist era, the position of the President of the Consistory was granted mostly to Lutheran Russian officials of German origin, mainly Generals of the Imperial Army. In the case of the Vice-President (General Superintendent), the nomination procedure was more liberal. In 1905, Polish Pastor Juliusz Bursche was appointed by the Tsar for the position of General Superintendent. Bursche had been forced to leave Poland during the first years of the First World War and was being held in Russia. ${ }^{10}$ After his exile, the office of the General Superintendent was given to his deputy, Pastor Rudolf Gundlach from Łódź. In 1916 German authorities appointed Count Hans Adam Nikolaus von Posadowsky-Wehner as the President of the Consistory. One of the positions in the Consistory was given to Bruno Geißler, the General Secretary of the Gustav Adolf Society, ${ }^{11}$ an organisation based in Leipzig whose main goal was to provide support to the German Protestant Churches outside of Germany. The Gustav Adolf Society granted young Lutherans from the Augsburg Church the opportunity to receive a theological education at the Leipzig University. Most of these students, such as Eduard Kneifel or Ernst Waldemar Krusche, ${ }^{12}$ actively supported the German nationalist cause in the Augsburg Church in Poland in the interwar period.

To separate the Church from the jurisdiction of the Polish Regency Council and the governmental departments, Hans von Beseler decided to call a General Synod. During this Synod, held on 17 and 18 October 1917 in Łódź, ${ }^{13}$ a project aimed at a new legal status, created by the President of the Gustav Adolf Society, Professor Franz Rendtorff, and Professor Otto Meyer, a lawyer from Leipzig, was discussed. ${ }^{14}$ According to this project, the Church was to be take on a more democratic structure, one where the synod was to be the main ruling body. The Church was also to gain a new status, formally declaring its independence from the state. ${ }^{15}$ Although the idea itself could be seen as modern and progressive today, back in 1917 it was considered a novelty. ${ }^{16}$ The project was also seen as a threat to the Polish members of the Church. According to Jakub Glass, the project itself proposed that the Church be of a German

${ }^{8}$ W. Gastpary, Protestantyzm w Polsce w dobie dwóch wojen światowych. 1914-1939, Warszawa 1978, p. 13.

${ }^{9}$ E. Kneifel, Geschichte der Evangelisch-Augsburgischen Kirche..., op. cit., p. 189.

${ }^{10}$ E. Kneifel, Die Pastoren der evangelisch-augsburgischen Kirche in Polen. Ein biographisches Pfarrerbuch mit einem Anhang, Eging 1967, p. 65.

${ }^{11}$ E. Kneifel, Geschichte der Evangelisch-Augsburgischen Kirche..., op. cit., p. 192.

12 Ibidem, p. 193.

13 J. Kłaczkow, op. cit., p. 85.

${ }_{14}$ B. Krebs, Państwo, Naród, Kościót. Biskup Bursche a spory o protestantyzm w Polsce w latach 1917-1939, Bielsko-Biała 1998, p. 26.

15 "Neue Lodzer Zeitung," vol. 16, no. 264, p. 3.

16 J. Glass, Ewangelicy polscy w świetle dokumentów urzędowych, Łódź 1919, pp. 47-48. 
national character, which, when enforced, could lead to the legal marginalisation of Polish Lutherans. ${ }^{17}$

Polish delegates who declared their loyalty to the edict of the Tsar from 1849, as well as German members of the Synod, opposed the new project and left the gathering, bringing the proceedings to a halt. ${ }^{18}$

The German nationalist pastors and theologians who had come to Poland with the occupying forces intended to create a new identity among Protestants living outside of the German Reich. According to Paul Althaus, this identity was to combine three factors: national origin, the Protestant faith, and trust in the German state. ${ }^{19}$ The German state, in Althaus' ethical thought, was seen as an "institutional defender of the interests of Germans from outside of the Reich." ${ }^{20}$ The activity of Althaus and other German activists also had certain political and military goals. The main task was to convince people, especially the younger generation, to sacrifice themselves for the greater cause of the German nation. ${ }^{21}$ This "greater cause" was obviously the ongoing war.

\section{After 1918: Independent state-dependent Church}

The Polish state, especially in the first years of the Second Polish Republic, worked towards establishing a new society based on loyalty towards the state. The patriotism and loyalty of Juliusz Bursche and other pastors and Lutheran activists, like Polish ministers from Cieszyn Silesia, towards the Polish government meant that for all Protestant Churches that found themselves in the new territory, the Augsburg Church was seen as a partner. As early as 1918, the Lutheran parishes in Cieszyn Silesia had joined the Consistory in Warsaw. ${ }^{22}$ Later on, the parishes in Volhynia, Podlasie and the region of Działdowo became attached to the Church. ${ }^{23}$ Other Protestant Churches, especially the Evangelical Church of the Union in Poland, the Evangelical Church of the Union in Polish Upper Silesia, and the Evangelical Church of the Augsburg and Helvetic Confession in Lower Poland demonstrated their insecurity amidst the new political reality. The Evangelical Church of the Union in Poland, with its Consistory in Poznan, which before the Uprising in Greater Poland was part of the Prussian Evangelical Church, even insisted on maintaining its formal bonds with the Church authorities in Berlin. ${ }^{24}$ Therefore, the pro-German tendencies in some of the German Protestant Churches in Poland were seen as a threat to the interests of the Polish state.

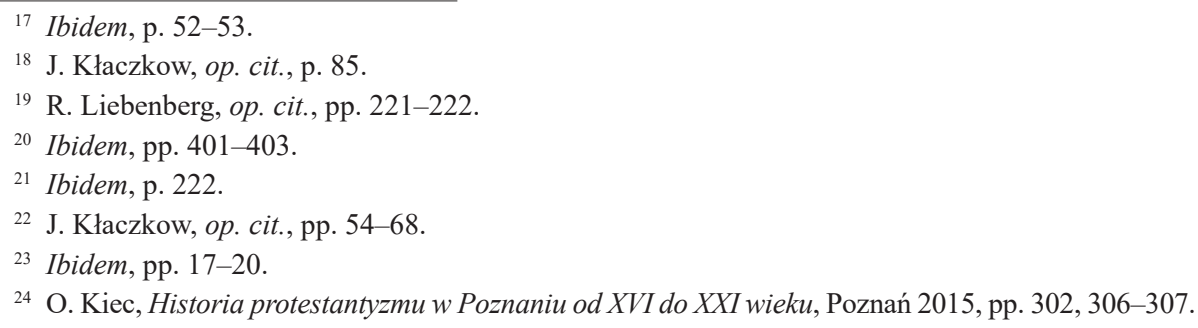


In the interwar period, until November 1936, the Augsburg Church retained its state-Church law introduced in 1849. The new dioceses of the Church that had been established when parishes from territories outside of Congress Poland were incorporated based their legal statuses on other laws. The congregations in Volhynia, Podlasie and Central Lithuania, which before the First World War were part of the Evangelical-Lutheran Church in Russia, had their laws guaranteed in another edict of the Russian Tsar from 1832. The congregations in Cieszyn Silesia based their legal statuses on the Austro-Hungarian bill from 1861. Prussian Church laws provided the legal basis for the functioning of the newly established Polish Lutheran parishes in the former Prussian provinces. This mixture of different state-Church regulations reflected the overall situation of the legal system in the first decade of the Second Polish Republic.

Views brought to Poland by the occupying forces during the First World War had a huge impact on the local pastors and Church activists, who even after the establishing of an independent Polish state saw themselves not only as guardians of the faith, but also of the language and culture. This led to the opposition of German Church ministers against the "polonisation" of Protestant congregations and public institutions in the early years of the independent Poland. Among their ranks was an entrepreneur from Łódź, a former trade representative of the German chemical consortium BASF and publisher, Adolf Eichler. ${ }^{25}$ Eichler was one of the main figures in the structures of the German Society for Lódź and Surroundings (German: Deutscher Verein für Lodz und Umgebung), a German nationalist political party founded in 1916. During the Synod of 1917 and after the war, Eichler preached the idea of a German National Church (German: Volkskirche) in the former Congress Poland, one that was to become fully independent from the Polish authorities. ${ }^{26} \mathrm{He}$ left Poland in 1919 and settled in Germany, but continued to support the idea of a separate German Lutheran Church in Central Poland and to provide financial support to the cause. ${ }^{27}$

General Superintendent Juliusz Bursche and Adolf Eichler, who as early as in 1918 explicitly showed their mutual reluctance towards each other, confronted each other once again during the 1920 East Prussia plebiscite. Bursche, along with other important Protestant intellectuals like Emilia Sukertowa-Biedrawina, tried to convince the Masurian Protestants to support the Polish cause. ${ }^{28}$ Eichler on the other hand, at that time stationed in Allenstein, actively supported the German views. In his article published in 1920 in "Evangelische Diaspora," the yearbook of the Gustav Adolf Society, Eichler accused Bursche of being too active in the political sphere and argued that his position of the General Superintendent was no longer seen as legitimate among German members of the Augsburg Church, and therefore a formal separation between Germans and Poles in the Augsburg Church should occur. ${ }^{29}$

${ }^{25}$ R. Liebenberg, op. cit., p. 227.

${ }^{26}$ B. Krebs, op. cit., p. 27.

${ }^{27}$ E. Kneifel, Geschichte der Evangelisch-Augsburgischen Kirche..., op. cit., p. 221.

28 J. Kłaczkow, op. cit., pp. 68-72.

29 A. Eichler, Die Evangelischen in Kongreßpolen am Scheidewege, "Die Evangelische Diaspora" 1920, vol. 2, pp. 197-200. 
Thus complicated situation led both the state and the Augsburg Church to begin their work to achieve a unified legal status. In April 1922, an amendment to the bill from 1849 that replaced the General Synod with the Constituting Synod was introduced by the Sejm. ${ }^{30}$ The main task of the new Church institution was to draft new and comprehensive legislation regarding state-Church relations.

In the 1920s the authorities attempted to establish a unified law for all mainline Protestant Churches in Poland. Two projects were discussed in the Sejm, one proposed by the right-wing politician Mikołaj Nader and the other by the Polish nationalist Catholic priest Kazimierz Lutosławski. Both were rejected by the Protestant Churches in Poland, including the Augsburg Church, as well as by the Sejm. ${ }^{31}$

During the eighteen sessions of the Constituting Synod, which began work in June 1922, two major visions of the Church status were discussed. One was intended to establish a unified Polish-German Church which would be fully acknowledged by the Polish state. The other vision was held by a group, which included German members of the Sejm August Utta, Josef Spickermann and Julian Will, working to establish two separate Church bodies, one for the Germans and the other for Poles, which would be acknowledged as "free" Churches, that is, fully independent from the state. ${ }^{32}$ Both parties reached a compromise in 1923, and the Synod was able to proceed further. The new legislation was developed and a legislative commission which consisted of various members of the Synod and represented the full spectrum of the Church was established, with the task of carrying out negotiations with the Ministry. ${ }^{33}$

The project of the legal status proposed by the Constituting Synod was sent to the Ministry in 1923. It took, however, almost four years for the government to respond. In 1927 the Church commission addressed a note to the Ministry, demanding further discussions. In this period the Government intended to establish a single legal status for all Protestant Churches. At the beginning of the 1930s it became clear that the predominantly German Churches, such as the Evangelical Church of the Union in Poland, would reject any propositions of the Polish state. Due to the willingness of Juliusz Bursche and other members of the synodal commission, the Augsburg Church was to be the first one to gain state-acknowledged legal status.

\section{After 1933: The introduction of the Bill for the Evangelical Church of the Augsburg Confession in Poland in 1936 and the Nazification of the German minority}

The conflict between Polish and German members of the Augsburg Church reached its peak in 1936, when, without any consultations in the Constitutional Synod, the Bill

${ }^{30}$ Dz. U. $1922 \mathrm{nr} 32$ poz. 257, Ustawa z dnia 27 kwietnia 1922 r. zmieniajaca postanowienia §\$152-162 ustawy dla Kościoła Ewangelicko-Augsburskiego w Królestwie Polskim z dnia 20 lutego 1849 r.

31 W. Gastpary, op. cit., pp. 103, 109-110.

${ }^{32}$ E. Kneifel, Geschichte der Evangelisch-Augsburgischen Kirche..., op. cit., p. 219.

33 Ibidem, p. 220. 
for the Evangelical Church of the Augsburg Confession in Poland was introduced. ${ }^{34}$ Furthermore, the growing popularity of the national socialist ideology among German intellectuals in Poland intensified the nationalist policy of particular Lutheran pastors and Church activists in Central Poland.

The bill itself was seen by the German group as undemocratic. In fact, even though the Constitutional Synod elected its representatives (Poles and Germans), who were responsible for preparing projects of the legal status, the major topics were discussed only between Juliusz Bursche and the Ministry. The premature publication of the text of the bill by the German press in Łódź was met with strong opposition from inside the Church. Also, Polish pastors like Zygmunt Michelis, the editor-in-chief of "Zwiastun Ewangeliczny," Feliks Gloeh, the military senior, and Senator Ludwik Józef Evert, member of the Synod and chairman of the parish council in Warsaw, warned that such regulations could only escalate the conflict inside the Church that had already led to its disunity, and would fully subordinate the Church to the will of the state. ${ }^{35}$ Another reason the bill was considered undemocratic was that it was introduced not by the Polish Sejm, where German Lutherans had their representatives and could discuss the proposed project on a political level, but by decree of the President of Poland, Ignacy Mościcki.

As a sign of opposition to the activity of the Consistory and the General Superintendent Juliusz Bursche, who had already shown his obedience towards the Ministry of Religious Confessions and Public Enlightenment, most German pastors unified themselves in 1935, establishing an organisation called the Working Group of German Pastors (German: Arbeitsgemeinschaft Deutscher Pastoren der EAK in Polen). Not every German pastor became a member of the organisation. There was also a group of ministers who wanted to avoid the conflict and neither supported nor opposed the Consistory.

Even though members of this organisation, led by Luck (Volhynia) Pastor Alfred Kleindienst, showed their partial support to the national socialist cause, in the theological manifesto of the Working Group Der Christ und das Volkstum, published in 1937 by one of its major activists, Pastor Ernst Waldemar Krusche from Rypin, the Arbeitsgemeinschaft declared its opposition to the racist views of Deutsche Christen in Germany. ${ }^{36}$

Krusche's manifesto was written in the spirit of the major German Lutheran theologians of the era. It was especially inspired by such authors as Paul Althaus ${ }^{37}$ and Werner Elert ${ }^{38}$ - theologians who on one hand declared their opposition towards the anti-Christian ideals of the Nazi movement, and on the other declared their support and obedience to the Nazi regime. The theological views in both cases concentrated on the idea of the Orders of Creation, where nation and race are explained as

${ }^{34}$ Dz. U. $1936 \mathrm{nr} 88$ poz. 613.

35 J. Kłaczkow, op. cit., pp. 88-89.

${ }_{36}$ W. Krusche, Der Christ und das Volkstum. Ein Beitrag zur klärung der völkischen Frage in unserer Kirche, Poznań 1936, p. 9.

${ }^{37}$ P. Althaus, Theologie der Ordnungen, Gütersloh 1935.

${ }^{38}$ W. Elert, Bekenntnis, Blut und Boden. Drei theologische Vorträge, Leipzig 1934. 
the inviolable ways of God's governorship over the world. Therefore, according to Krusche, the Church was also responsible for maintaining the national identity of its members. ${ }^{39}$

Many members of the Arbietsgemeinschaft showed their fascination towards the Nazi regime in Germany. ${ }^{40}$ Pastor Jakob Gerhardt from Bełchatów even stated that Hitler was the "saviour of the German nation."

Such declarations spread throughout Poland among the German political movements, especially after the Polish and German governments signed the non-aggression pact of 1934. This situation gave rise to declarations that there was nothing wrong with being a national socialist and a loyal citizen of Poland.

The policy of the Polish government, which was intended to keep public institutions free from the influences of the German minority, inflamed the anti-governmental attitude of many German pastors. The 'polonisation' of the German public schools was met with strong opposition. ${ }^{42}$

Furthermore, the bill for the Augsburg Church that was finally introduced in November 1936 included many regulations which many pastors considered dangerous. The new state-Church law obliged pastors to openly declare their loyalty towards the Polish state, to pray for the prosperity of the Polish state and the President of Poland, and to celebrate Church services during state holidays like Independence Day. Other laws were even more worrying to many pastors. According to the bill, any pastor running as a candidate for the position of a diocesan senior (superintendent), could be rejected by the state for political reasons.

After November 1936, any clear sign of opposition against the new state-Church regulations could have been interpreted by the state as an act of disobedience against the public law. In fact, the bill for the Augsburg Church was not only an internal matter of the Church, but also of the state. Disobeying the law was therefore not only an act of protest against the Consistory and Juliusz Bursche, but also an offence against the Polish authorities.

Considering the political activity of pastors, this regulation proved its effectiveness during the first elections of the diocesan synods and seniors, held in the spring of 1937. The regional police authorities were instructed to gather information about the particular candidates, ordained and non-ordained, including their political and social views and whether their activity was a threat to the Polish state. ${ }^{43}$ Such information could later be used to discredit the German candidates. This action, however, did not directly affect all of the Germans in the Church. German pastors who wanted to keep themselves out of the conflict were sometimes reported positively by the police, such

39 W. Krusche, op. cit.

${ }^{40}$ B. Krebs, op. cit., pp. 138-139.

41 APPT, Starostwo Powiatowe Piotrkowskie, vol. 12. sign. 2048, nn., Police report from 3rd March 1937 about the social and political activity of pastor Jakob Gerhardt in Betchatów.

${ }^{4}$ E. Kneifel, Geschichte der Evangelisch-Augsburgischen Kirche..., op. cit., pp. 227-232.

43 APPT, Starostwo Powiatowe Piotrkowskie, vol. 12, sign. 2048, nn., Secret order of the regional authorities in Piotrków issued on 19 March 1937, addressed to the local police authorities to gather information about the candidates to the Evangelical-Augsburg diocesan bodies. 
as Pastor Max Petznik from Piotrków Trybunalski, ${ }^{44}$ who later became the presbyter of the diocese of Piotrków without any objections from the state.

During the election of the Senior of the Diocese of Kalisz, when Pastor Adolf Ulbrich from Grodziec gained the majority of votes, the formal democratic election was not approved by the Ministry and General Superintendent Bursche. ${ }^{45}$ As a consequence, the Consistory appointed Polish Pastor Edward Wende from Kalisz to the position of the commissary senior of the diocese. ${ }^{46} \mathrm{~A}$ similar scenario played out in Tomaszów Mazowiecki, during the election of the senior of the Piotrków Diocese. Even though he had gained the majority of votes, Pastor Jakob Gerhardt from Bełchatów was rejected by the state, and Bursche ordered the votes to be re-cast. The second election was won by Pastor Leon May from Tomaszów Mazowiecki, who, like Pastor Wende from Kalisz, declared himself a Pole. ${ }^{47}$ The leader of the German National Union in Poland and member of the Lask parish, August Utta, who previously served as a delegate to the Constitutional Synod, was now rejected as a candidate by the Consistory. ${ }^{48}$

The newly created diocese of Łódź, where most of the Lutherans declared German nationality, refused to hold elections as a sign of protest. This step was followed by the dioceses of Płock and Volhynia, in both of which the Consistory had to appoint commissary seniors. ${ }^{49}$

The elections of diocesan offices led to a boycott of the elections of the General Synod. This movement was inspired by the Foreign Office of the German Evangelical Church in Berlin, which remained closely affiliated with the Arbeitsgemeinschaft. Senior representatives of the Working Group regularly visited the Free City of Danzig, where both German and Polish citizens could travel without any legal restrictions, and discussed the situation in Poland with Church representatives from the Reich. ${ }^{50}$

The boycott itself ended as a failure of the Arbeitsgemeinschaft. Even though many members of the Working Group and German political activists in Poland called on Church members not to attend the elections, the pro-Bursche group gained a majority and the Synod was able to proceed without any obstacles. ${ }^{51}$

The Polish state and the Consistory both sought to limit the influences of the senior members of the Arbeitsgemeinschaft. In September 1938, the Voivode of Volhynia stripped Alfred Kleindienst of his Polish citizenship. ${ }^{52}$ The decision itself may seem

\footnotetext{
${ }^{44}$ APPT, Starostwo Powiatowe Piotrkowskie, vol. 12, sign. 2048, nn., Police report from 3 March 1937 about the social and political activity of pastor Max Petznik from Piotrków.

${ }^{45}$ E. Kneifel, Geschichte der Evangelisch-Augsburgischen Kirche..., op. cit., p. 273.

${ }^{46}$ Ibidem.

${ }^{47}$ Ibidem.

${ }^{48}$ Ibidem, p. 272.

49 J. Kłaczkow, op. cit., p. 92.

${ }^{50}$ B. Krebs, op. cit., pp. 192-194.

${ }^{51}$ Ibidem, pp. 192-198.

52 Ibidem, p. 209.
} 
controversial even to this day. ${ }^{53}$ Pastor Kleindienst was born in Łuck in 1893, when the region of Volhynia was a part of Russia. After completing theological studies in Dorpat, he served as a vicar in Tsarskoye Selo and then was ordained in Moscow in April 1918. He had fled to Poland in 1921 and, after positive verification by the state, was able to carry on his ministry in Łuck, which now had become a parish of the Augsburg Church. ${ }^{54}$ As a consequence of the new legal status of the Church, Pastor Kleindienst was dismissed by the Consistory, because, according to the regulations, only a Polish citizen could serve as a pastor in the Augsburg Church. ${ }^{55}$ The situation of Pastor Kleindienst was widely observed in Germany and was even discussed between German Foreign Minister Joachim von Ribbentrop and his Polish counterpart Józef Beck. ${ }^{56}$

Other active members of the Arbeitsgemeinschaft were either removed from their offices or threatened by the state authorities with dismissal by the Consistory if they would not accept the new Church-state regulations. A few months before the outbreak of the Second World War Juliusz Bursche, who in 1937 had been appointed the first Bishop of the Church, also refused to ordain theology graduates who expressed national socialist views. ${ }^{57}$

The new situation of the Church after 1936 also exacerbated conflicts between parishioners and their pastors. These conflicts were especially present in congregations where a large number of their members declared German nationality, but the pastor considered himself a Pole, or a Pole of German origin. The growing popularity of the national socialist ideology among members of the German People's Union in Poland, which in 1937 reached 25,000 members, was one of the main factors. Pastors of the Arbeitsgemeinschaft who wanted to accept the new situation of the Church and were trying to fulfil the new requirements found themselves under pressure from the leading members of their parishes and had to publicly express their opposition towards Bursche. ${ }^{58}$ The German People's Union in Poland, a conservative party established in 1924, now turned in a more national socialist direction. It adopted the new style of political rallies, uniforms, and habits. The biggest change in the movement came in 1938, when its leader August Utta was replaced with Ludwig Wolff the Younger, who openly expressed his fascination with the Nazi ideas. During his presidency of the party the German People's Union in Poland was subordinated to the SS-Hauptamt Volksdeutsche Mittelstelle, a branch of the Nazi state responsible for the spread of national socialist ideology among Germans living outside of the German Reich. ${ }^{59}$

${ }^{53}$ Especially that the same fate met the family of pastor Kleindienst, conf. E. Kneifel, Bischof Dr. Julius Bursche. Sein Leben und seine Tätigkeit 1862-1942, Vierkirchen 1980, p. 149.

${ }^{54}$ E. Kneifel, Die Pastoren..., op. cit., pp. 110-111.

${ }_{55}$ B. Krebs, op. cit., p. 209.

${ }_{56}$ E. Kneifel, Geschichte der Evangelisch-Augsburgischen Kirche..., op. cit., p. 286.

${ }^{57}$ B. Krebs, op. cit., pp. 227-228.

58 W. Gastpary, op. cit., pp. 254-255.

${ }^{59}$ W. Chu, "Volksgemeinschaften unter sich." German Minorities and Regionalism in Poland, 1918 1939, [in:] German History from the Margins, N. Gregor, N. Roemer, M. Roseman (eds.), Bloomington 2006, pp. 119-120. 
Among all the senior members of the Arbeitsgemeinschaft one further person is worth mentioning: Julius Dietrich, first pastor of the St. John's Parish in Łódź, which at the time was the biggest congregation of the Augsburg Church (approx. 16,500 members) ${ }^{60}$ Even though he expressed a strong German national attitude, he had shown a moderate approach towards the conflict between both sides. In 1905, after massive strikes by textile workers, Dietrich, alongside Polish Pastor Karol Serini from Zgierz and his German colleague Pastor Rudolf Schmidt from Pabianice, organised the Trade Union of Christian Workers in Łódź, whose main goal was to reach compromises between workers and factory owners. During the First World War Pastor Dietrich established a network of charity organisations which provided healthcare and material support to the victims of the war. During the interwar period he was also active in the social and missionary field. Thanks to his efforts, many musical, social care and missionary institutions, such as the Lodzer Bahnhofsmission, were established. For his merits he was decorated by the Polish authorities with the Order of Polonia Restituta. For many years, he was the sole German representative in the Consistory. ${ }^{61}$

After the introduction of the bill, Dietrich was on one hand a supporter of the German interest in the Augsburg Church, but on the other he was making efforts to restore the unity of the Church. This position, along with the positive verification of the state authorities, guaranteed him the position of commissary senior of the diocese of Łódź, which was established in 1936. His moderate approach stood in an opposition to the radical members of the Arbeitsgemeinschaft, such as another pastor from Łódź, Adolf Doberstein. ${ }^{62}$

\section{Conclusion}

The rise of German nationalism among the German minority in Central Poland was among the factors leading to the internal conflict in the Evangelical Church of the Augsburg Confession in Poland. This type of minority-nationalism was based on the idea of ethnic integrity of the German group, bound together not only by the language and culture but also by the common religion. All of these elements of identity were reflected in social life by the institutions, and in the case of religion by the Lutheran Church. Theological factors, such as the Lutheran doctrine of orders, rethought by such theologians as Paul Althaus or Werner Elert, presented the nation (understood as an ethnic group) as one of the ways God manifests His creation. These political and theological concepts of nationhood found fertile ground in interwar Central Poland, where German pastors and Church activists as well as minority politicians struggled to protect the elements of their ethnic identity from the interference of the Polish state. This situation, combined with the actions undertaken by the state, led

${ }^{60}$ E. Kneifel, Die evangelisch-augsburgischen Gemeinden in Polen 1555-1939, Vierkirchen 1971, p. 165.

${ }^{61}$ E. Kneifel, Die Pastoren..., op. cit., pp. 77-80.

${ }^{62}$ B. Krebs, op. cit., p. 204. 
to conflicts with the pro-governmental Consistory under Bishop Juliusz Bursche and eventually, to further divisions within the Church.

\section{References}

\section{Publications}

Althaus P., Theologie der Ordnungen, Gütersloh 1935.

Chu W., "Volksgemeinschaften unter sich.” German Minorities and Regionalism in Poland, 1918 1939, [in:] German History from the Margins, N. Gregor, N. Roemer, M. Roseman (eds.), Bloomington 2006, pp. 119-120.

Ciecieląg P., Jóźwiak E., Godfrejow-Tarnogórska A. (eds.), 500 lat Reformacji w Polsce, Warszawa 2017.

Eichler A., Die Evangelischen in Kongreßpolen am Scheidewege, "Die Evangelische Diaspora" 1920, vol. 2, pp. 197-200.

Elert W., Bekenntnis, Blut und Boden. Drei theologische Vorträge, Leipzig 1934.

Gastpary W., Protestantyzm w Polsce $w$ dobie dwóch wojen światowych. 1914-1939, Warszawa 1978.

Glass J., Ewangelicy polscy w świetle dokumentów urzędowych, Łódź 1919.

Kiec O., Historia protestantyzmu w Poznaniu od XVI do XXI wieku, Poznań 2015.

Kłaczkow J., Kościót Ewangelicko-Augsburski w Polsce w latach 1918-1939, Torun 2018.

Kneifel E., Bischof Dr. Julius Bursche. Sein Leben und seine Tätigkeit 1862-1942, Vierkirchen 1980.

Kneifel E., Die evangelisch-augsburgischen Gemeinden in Polen 1555-1939, Vierkirchen 1971.

Kneifel E., Geschichte der Evangelisch-Augsburgischen Kirche in Polen, Niedermarschacht über Winsen/Luhe 1962.

Kneifel E., Die Pastoren der evangelisch-augsburgischen Kirche in Polen. Ein biographisches Pfarrerbuch mit einem Anhang, Eging 1967.

Krebs B., Państwo, Naród, Kościót. Biskup Bursche a spory o protestantyzm w Polsce $w$ latach 1917-1939, Bielsko-Biała 1998.

Krusche W., Der Christ und das Volkstum. Ein Beitrag zur klärung der völkischen Frage in unserer Kirche, Poznań 1936.

Liebenberg R., Der Gott der feldgrauen Männer. Die theozentrische Erfahrungstheologie von Paul Althaus d. J. im Ersten Weltkrieg, Leipzig 2008.

\section{Press articles}

“Neue Lodzer Zeitung," vol. 16, no. 264, p. 3.

Legal acts

Dz. Pr. 1849 t. 42, nr 129, Ustawa dla Kościoła Ewangelicko-Augsburskiego w Królestwie Polskiem.

Dz. U. 1922 nr 32 poz. 257, Ustawa z dnia 27 kwietnia 1922 r. zmieniajaca postanowienia § 152-162 ustawy dla Kościoła Ewangelicko-Augsburskiego w Królestwie Polskim z dnia 20 lutego $1849 \mathrm{r}$.

Dz. U. 1936 nr 88 poz. 613, Dekret Prezydenta Rzeczypospolitej z dnia 25 listopada 1936 r. o stosunku Państwa do Kościoła Ewangelicko-Augsburskiego w Rzeczypospolitej Polskiej.

\section{Archival materials}

APPT (Archiwum Państwowe w Piotrkowie Trybunalskim), Starostwo Powiatowe Piotrkowskie, vol. 12. sign. 2048. 